\title{
Antimicrobial activity of Mimosa tenuiflora (Willd.) Poir. from Northeast Brazil against clinical isolates of Staphylococcus aureus
}

\author{
Itácio Q. M. Padilha, ${ }^{1}$ Andréia V. Pereira, ${ }^{2}$ Onaldo G. Rodrigues, ${ }^{2}$ José P. Siqueira-Júnior, ${ }^{* 1}$ \\ Maria do Socorro V. Pereira ${ }^{1}$ \\ ${ }^{1}$ Departamento de Biologia Molecular, Universidade Federal da Paraiba, 58059-900 João Pessoa-PB, Brasil \\ ${ }^{2}$ Departamento de Medicina Veterinária, Universidade Federal de Campina Grande, 58700-970 Patos-PB, Brasil
}

\begin{abstract}
RESUMO: "Atividade antimicrobiana de Mimosa tenuiflora (Willd.) Poir. do Nordeste do Brasil, contra isolados clínicos de Staphylococcus aureus". A Mimosa tenuiflora é uma planta nativa da região Nordeste do Brasil onde é conhecida como jurema-preta sendo amplamente utilizada na medicina popular. No presente trabalho a atividade anti-Staphylococcus aureus do extrato etanólico da M. tenuiflora foi avaliada pela determinação da concentração inibitória mínima (CIM), pelo método da diluição em agar, em 30 isolados clínicos e pela cinética de inativação com a linhagem referência. Os valores da CIM foram $0,18 \mathrm{mg} / \mathrm{mL}$ em 16 isolados e $0,36 \mathrm{mg} / \mathrm{mL}$ nos demais, bem como na linhagem referência. A cinética de inativação mostrou apenas efeito bacteriostático nas concentrações do extrato até aquela correspondente a $4 \mathrm{x}$ CIM e um rápido efeito bactericida na concentração correspondente a 8x CIM.
\end{abstract}

Unitermos: Mimosa tenuiflora, extrato etanólico, atividade antimicrobiana, Staphylococcus aureus.

\begin{abstract}
Mimosa tenuiflora is a native plant of Northeast Brazil where it is popularly known as "jurema-preta" and it is widely used in folk medicine. In this work the anti-Staphylococcus aureus activity of ethanol extract of $M$ tenuiflora was evaluated by determination of minimum inhibitory concentration (MIC) of clinical isolates by the agar dilution method, and by time-kill assay using a reference strain. MIC values against 30 isolates were $0,18 \mathrm{mg} / \mathrm{mL}(16 / 30)$ or $0,36 \mathrm{mg} /$ $\mathrm{mL}(14 / 30$, and also the reference strain). In the reference strains, at concentrations up to $4 \mathrm{x}$ MIC, only bacteriostatic effect was observed, but at $8 \mathrm{x}$ MIC a fast bactericidal effect was observed.
\end{abstract}

Keywords: Mimosa tenuiflora, ethanol extract, antimicrobial activity, Staphylococcus aureus.

\section{INTRODUCTION}

Staphylococcus aureus is recognized as an important community-acquired and major nosocomial pathogen responsible for a wide range of infections. Although the introduction of antibiotics, since the early 1950s, has reduced morbidity and mortality due to $S$. aureus infections, this Gram-positive bacteria have developed/acquired resistance mechanisms to practically all antibiotics that have been introduced in clinical practice (Lowy, 2003; Hardy et al., 2004). Indeed, methicillinresistant $S$. aureus (MRSA) are often multidrug-resistant, a serious problem worldwide. New antimicrobial agents are urgently needed and currently there has been increasing interest in evaluating the antimicrobial activity of plant natural products - extracts and phytochemicals (Gibbons, 2004, 2008; Stavri et al., 2007).

Mimosa tenuiflora (Willd.) Poir. (Mimosaceae; Fabaceae-Mimosoideae) is a perennial evergreen tree or shrub native of Northeast Brazil where is popularly known as "jurema-preta". It is used in folk medicine against bronchitis, coughs, fever, headache and external ulcers, and in Indigenous and Afro-Brazilian cults as entheogen (Albuquerque et al., 2007; Agra et al., 2008; Souza et al, 2008). Phytochemical investigations of $M$. tenuiflora resulted in the isolation of several classes of compounds, including indole alkaloids, tannins, chalcones, steroids, terpenoids and phenoxychomones (Rivera-Arce et al., 2007; Souza et al., 2008 and references therein).

Despite the existence of reports focusing on the antimicrobial activity of M. tenuiflora (Lozoya et al., 1989; Meckes-Lozoya et al., 1990; Heinrich et al., 1992), studies concerning local bacterial isolates as well as extracts from local plant specimens are warrant. In this work we evaluated the antimicrobial activity of ethanol extract of M. tenuiflora (EEMt) against strains of $S$. aureus isolated from a Brazilian university hospital.

\section{MATERIAL AND METHODS}

Plant material and preparation of EEMt 
Steam bark of M. tenuiflora was collected in a county (São José dos Espinharas) of the semi-arid region of the State of Paraiba, Brazil. The plant material was identified by Lúcio Valério Coutinho and a voucher specimen $\left(\mathrm{n}^{\circ}\right.$ HC001) is deposited at the Herbarium "Caatinga" (Universidade Federal de Campina Grande). Dried and powdered steam bark (100 g) was exhaustively extracted with ethanol using a Soxhlet apparatus. The concentrate solution $(57.8 \mathrm{mg} / \mathrm{mL})$ obtained was stored at ca. $4{ }^{\circ} \mathrm{C}$ until using.

\section{Bacterial strains}

Thirty isolates of $S$. aureus obtained at the Universidade Federal da Paraíba Hospital. (Freitas et al., 1999) and the reference strain ATCC 25923 were tested All strains were maintained on blood agar base (Difco) slants and, prior to use, the cells were grown overnight at $37^{\circ} \mathrm{C}$ in brain heart infusion broth (Difco).

\section{Susceptibility testing}

The minimum inhibitory concentrations (MIC) of the EEMt were determined by the agar dilution method using an inoculum of $c a .10^{4}$ cfu (colony forming unit) (Pereira \& Siqueira-Junior, 1995). The extract concentration range in the Müller-Hinton (M-H agar (Difco) plates was 5.78 to $0.011 \mathrm{mg} / \mathrm{mL}$ (two-fold serial dilutions). The MIC is defined as the lowest extract concentration at which no growth is observed after $18-24 \mathrm{~h}$ incubation at $37^{\circ} \mathrm{C}$.

\section{Time kill assay}

The bacteria were grown in Müeller-Hinton broth (Difco) until they reached late exponential phase (16-18 h at $37^{\circ} \mathrm{C}$ ) and resuspended in the same medium at a density of $c a .10^{6} \mathrm{cfu} / \mathrm{mL}$. Extract was added to obtain final concentrations of MIC, 2x MIC, 4x MIC and 8x MIC, and the cultures incubated at $37^{\circ} \mathrm{C}$ without agitation. Aliquots $(100 \mu \mathrm{L})$ were taken at $0,30,60$ and $120 \mathrm{~min}$, serially diluted in saline and spread-plated onto Müller-Hinton agar. After $18-24 \mathrm{~h}$ of incubation at $37^{\circ} \mathrm{C}$, colonies were counted and the relative bacterial titer calculated (bacterial titer at time $\mathrm{t} /$ bacterial titer at time 0 ). In the control, no extract was added.

\section{RESULTS AND DISCUSSION}

MIC values of EEMt against the thirty clinical isolates of $S$. aureus were $0,18 \mathrm{mg} / \mathrm{mL}(16 / 30)$ or 0,36 $\mathrm{mg} / \mathrm{mL}(14 / 30$, and also the strain ATCC 25923). The steam bark ethanol extract of the same species have been mentioned in the literature for their antibacterial activity on Staphylococcus epidermitis, Escherichia coli, Pseudomonas aeruginosa and antifungal activity on Candida albicans (Lozoya et al., 1989; Meckes-Lozoya et al., 1990). Studies performed by Mexican research groups support the biological activities by the existence of compounds as steroids, terpenoids, alkaloids, flavanoids, tannins, chalcones and other phenolic compounds in Mimosae tenuiflora (Rivera-Arce et al., 2007).

Most studies on plant extracts are based on the measurement of MIC. One limitation of this procedure is the inability of the method to determine how quickly an agent act on the organism. The present study was improved with time-kill essay.

Previous experiments demonstrated at $5.78 \mathrm{mg} /$ $\mathrm{mL}$ a decrease in the UFC below the limit of quantification after two hours of exposure. Figure 1 shows the effect of different concentrations of EEMt on cell viability of the reference strain ATCC 25923. All time-kill assays were repeated twice, with consistent results. At concentrations up to $4 \mathrm{x}$ MIC, only an inhibitory (bacteriostatic) effect was observed even after two hours of exposure. At 8x MIC, a bactericidal effect $\left[\geq 3 \log _{10}\right.$ reduction in viable cells, i.e., $\geq 99,9 \%$ kill (LaPlante, 2007)] was observed already after $30 \mathrm{~min}$ of exposure. This concentration did not prevent a regrowth of the surviving bacteria after one hour, not exceeding, however, $1 \log _{10}$ increase in viable cells up to two hours.

These data are promising and could encourage further researches on phytochemical, toxicological and pharmacological aspects of $M$. tenuiflora by-products in order to support their possible rational use in the antimicrobial therapy, particularly in anti-S. aureus therapy.

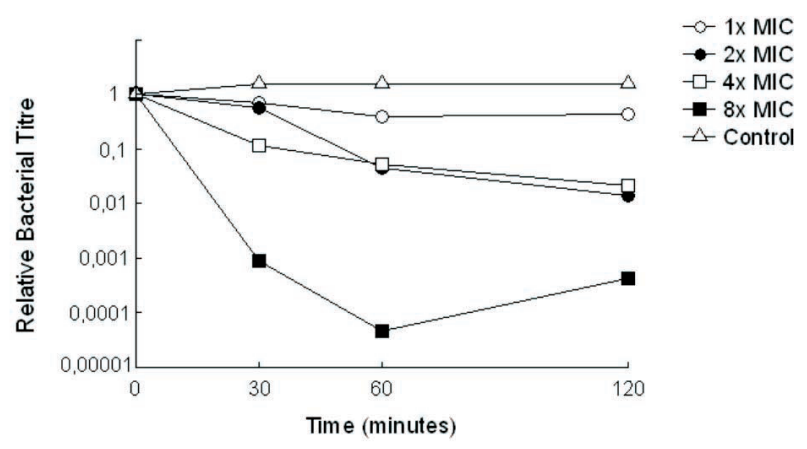

Figure 1. Effect of the ethanol extract of Mimosa tenuiflora at differente concentration on the cell viability of Staphylococcus aureus ATCC 25923.

\section{ACKNOWLEDGEMENTS}

I.Q.M.P. is very grateful to Amely Branquinho Martins for helpful discussion during the course of this work. This work was supported by the Brazilian agencies $\mathrm{CNPq}(\mathrm{PIBIC} / \mathrm{UFPb})$ and FAPESQ-PB. 


\section{REFERENCES}

Agra MF, Silva KN, Basílio IJLD, Freitas PF, Barbosa-Filho JM 2008. Survey of medicinal plants used in the region Northeast of Brazil. Rev Bras Farmacogn 18: 472-508.

Albuquerque UP, Medeiros PM, Almeida ALS, Monteiro JM, Lins-Neto EMF, Melo JG, Santos JP. 2007. Medicinal plants of the caatinga (semi-arid) vegetation of $\mathrm{NE}$ Brazil: A quantitative approach. J Ethnopharmacol 114: 325-354.

Freitas FIS, Guedes-Stehling E, Siqueira-Junior JP 1999. Resistance to gentamicin and related aminoglycosides in Staphylococcus aureus isolated in Brazil. Lett Appl Microbiol 29: 197-201.

Gibbons S 2004. Anti-staphylococcal plant natural products. Nat Prod Rep 21: 263-277.

Gibbons S 2008. Phytochemical for bacterial resistance strengths, weaknesses and opportunities. Planta Med 74: 594-602.

Hardy KJ, Hawkey PM, Gao F, Oppenheim BA 2004. Methicillin resistant Staphylococcus aureus in the critically ill. Brit J Anaesth 92: 121-130.

Heinrich M, Kuhnt M, Wright CW, Rimpler H, Phillipson JD, Schandelmaier A, Warhurst DC 1992. Parasitological and microbiological evaluation of Mixe Indian medicinal plants (Mexico). J Ethnopharmacol 36: 81-85.

LaPlante KL 2007. In vitro activity of lysostaphin, mupirocin, and tea tree oil against clinical methicillin-resistant Staphylococcus aureus. Diagn Microbiol Infect Dis 57: 413-418.

Lowy FD 2003. Antimicrobial resistance: the example of Staphylococcus aureus. J Clin Invest 111: 1265-1273.

Lozoya X, Navarro V, Arnason JT, Kourany E 1989. Experimental evaluation of Mimosa tenuiflora (Willd.) Poir. (Tepeschohuite) I. Screening of the antimicrobial properties of bark extracts. Arch Invest Med (Mex) 20: 87-93.

Meckes-Lozoya M, Lozoya X, Gonzalez JL 1990. Pharmacological properties in vitro of various extracts of Mimosa tenuiflora (tepescohuite). Arch Invest Med (Mex) 21: 163-169.

Pereira MSV, Siqueira-Junior, JP 1995. Antimicrobial drug resistance in Staphylococcus aureus isolated from cattle in Brazil. Lett Appl Microbiol 20: 391-395.

Rivera-Arce E, Gattuso M, Alvarado R, Zárate E, Agüero J, Feria I, Lozoya X 2007. Pharmacognostical studies of the plant drug Mimosae tenuiflorae cortex. J Ethnopharmacol 113: 400-408.

Souza RSO, Albuquerque, UP, Monteiro, JM, Amorim, ELC 2008. Jurema-Preta (Mimosa tenuiflora [willd] Poir): a review of its traditional use, phytochemistry and pharmacology. Braz Arch Biol Technol 51: 937-947.

Stavri M, Piddock LJV, Gibbons, S. 2007. Bacterial efflux pump inhibitors from natural sources. J Antimicrob Chemother 59: $1247-1260$ 